\title{
KONSEP DAN KRITERIA KECAKAPAN BERTINDAK BAGI PENYANDANG DISABULITAS AUTISME MENURUT PERSEFEKTIF HUKUM PERDATA INDONESIA
}

\author{
Endra Agus Setiawan \\ Program Studi Magister Kenotariatan, Fakultas Hukum \\ Universitas Brawijaya, Jalan Abdul Muis 52-56A, Jakarta, 10160 \\ Email:nd12agus@gmail.com \\ Siti Hamidah \\ Program Studi Magister Kenotariatan, Fakultas Hukum \\ Universitas Brawijaya, Jalan Abdul Muis 52-56A, Jakarta, 10160 \\ Istislam \\ Program Studi Magister Kenotariatan, Fakultas Hukum \\ Universitas Brawijaya, Jalan Abdul Muis 52-56A, Jakarta, 10160
}

\begin{abstract}
This paper discusses the concepts and criteria of savoir faire for autism persons with disabilities in the Indonesian civil law perspective. The issues discussed in this study are related to the concept and criteria of savoir faire that apply to people with autism disabilities after the law is invited Act No. 8 of 2016 on Persons with Disabilities as a substitute Act no. 4 of 1997. In Article 4 paragraph 1 letter (c) of the Disability Law, autism disabilities fall into the category of mental disability, whereas Autism is developmental disability and differs from mental disability as schizophrenia, bipolar, depression, anxiety, and personality disorders. By placing autism disability into a mental disability will lead to the perception that a person with autism disability is a person who must be put under the ability because it is considered incompetent. This writing is compiled with normative legal research method with the approach of legislation and conceptual. The results of the study show that persons with autism disabilities are competent legal subjects if they meet the criteria of proficiency as defined in 1330 Civil Code and as long as they are not declared incompetent based on court decision (Elucidation of Article 32 of the Law of Persons with Disabilities).
\end{abstract}

Keywords: Mental Disability, Autism Disabilities, and Savoir Faire

\begin{abstract}
Abstrak
Tulisan ini membahas tentang konsep dan kriteria kecakapan bertindak bagi penyandang disabilitas autisme menurut persefektif hukum perdata Indonesia. Permasalahan yang dibahas dalam penelitian ini terkait tentang konsep dan kriteria kecakapan bertindak yang berlaku bagi penyandang disabilitas autisme pasca di undangkannya Undang-Undang No. 8 tahun 2016 tentang Penyandang Disabilitas sebagai pengganti Undang-Undang No. 4 tahun 1997 tentang Penyandang Cacat. Di dalam Pasal 4 ayat 1 huruf (c) UU Penyandang Disabilitas, disabilitas autisme masuk kedalam kategori disabilitas mental, padahal Autisme adalah disabilitas perkembangan dan berbeda dengan disabilitas mental sebagaimana skizofrenia, bipolar, depresi, anxietas, dan gangguan kepribadian. Dengan menempatkan disabilitas autisme ke dalam disabilitas mental akan menimbulkan persepsi bahwa seorang dengan disabilitas autisme adalah seorang yang harus ditaruh dibawah pengampuan karena dianggap tidak cakap. Penulisan ini disusun dengan normatif legal research method dengan pendekatan peraturan perundang-undangan dan konseptual. Hasil penelitian menunjukan bahwa penyandang disabilitas autisme adalah subyek hukum yang cakap jika memenuhi kriteria kecakapan sebagaimana yang ditentukan dalam 1330 KUHPerdata dan selama tidak dinyatakan tidak cakap berdasarkan penetapan pengadilan (penjelasan Pasal 32 UU Penyandang Disabilitas).
\end{abstract}

Kata kunci: Penyandang Disabilitas Mental, Penyandang Disabilitas Autisme dan Kecakapan Bertindak 


\section{Pendahuluan}

Setiap manusia dilahirkan unik dan luar biasa, beberapa mempunyai perbedaan yang disebut kebutuhan khusus. Seseorang yang dilahirkan dengan kebutuhan khusus diberi label manusia yang tidak sempurna atau biasa disebut cacat, dan seorang cacat adalah yang memiliki atau menyandang kelainan fisik dan/atau mental, dimana kelainan fisik tersebut merupakan suatu hal yang dapat mengganggu kehidupan orang tersebut dan merupakan rintangan serta hambatan baginya untuk melakukan kehidupan normal sebagaimana mestinya. ${ }^{1}$ Penggunaan istilah cacat pada saat ini tidak relevan lagi digunakan, karena kata cacat berkonotasi negatif, dan sering ditafsirkan sebagai sesuatu yang rusak dan suatu yang dianggap tidak normal, seorang yang cacat distigmakan sebagai orang yang lemah atau tidak mampu berbuat sesuatu, baik untuk dirinya sendiri maupun untuk orang lain. Disadari atau tidak, penyebutan bagi seseorang yang dianggap cacat mempunyai dampak terhadap tindakan diskriminatif bagi orang yang diberi label cacat oleh orang yang normal.

Pada tanggal 15 April 2016 pemerintah Indonesia mengesahkan Rancangan Undang-Undang Tentang Penyandang Disabilitas menjadi UndangUndang Nomor 8 Tahun 2016 tentang Penyandang Disabilitas (UU Penyandang Disabilitas) dalam Lembaran Negara Tahun 2016 Nomor 69. Dengan diundangkannya UU Penyandang Disabilitas, maka
Undang-Undang No. 4 Tahun 1997 tentang Penyandang Cacat telah dinyatakan tidak berlaku lagi dan dengan terbitnya UU Penyandang Disabilitas, maka penggunaan istilah cacat bagi orang yang memiliki kekurangan baik fisik maupun mental pada sekarang ini telah diganti dengan istilah disabilitas (disability). ${ }^{2}$ UU Penyandang Disabilitas merupakan suatu acuan hukum (kerangka hukum) bagi pemenuhan hak-hak para penyadang disabilitas, guna memberikan kesempatan yang setara dan untuk memerangi pemisahan, pelembagaan dan pengecualian bagi para penyandang disabilitas sebagai bentuk diskriminasi kecacatan yang khas. UU Penyandang Disabilitas mengakui bahwa penyandang disabilitas adalah subyek hukum ${ }^{3}$ karenanya memiliki hak dan kewajiban yang sama dengan manusia lainnya. ${ }^{4}$ Namun bukan berarti dapat menjalankan hak dan kewajibannya secara langsung, maksudnya adalah seorang penyandang disabilitas memiliki kewenangan, namun tidak semua memiliki kecakapan sehingga dengan kondisi tertentu perbuatan hukumnya diwakili oleh subyek hukum lainnya yang ditentukan oleh undang-undang. Pasal 32 UU Penyandang Disabilitas menyatakan bahwa "Penyandang Disabilitas dapat dinyatakan tidak cakap berdasarkan penetapan pengadilan negeri. Dan di dalam penjelasan pasal 32 dikatakan, bahwa orang yang "tidak cakap" adalah orang yang belum dewasa dan/atau dibawah pengam-

Pengertian istilah cacat yang terdapat di dalam Pasal 1 ayat (1) Undang-Undang Nomor 4 Tahun 1997 tentang Penyandang Cacat.

2 Pasal 1 ayat (1) UU Penyandang Disabilitas, Penyandang Disabilitas adalah setiap orang yang mengalami keterbatasan fisik, intelektual, mental, dan/atau sensorik dalam jangka waktu lama yang dalam berinteraksi dengan lingkungan dapat mengalami hambatan dan kesulitan untuk berpartisipasi secara penuh dan efektif dengan warga negara lainnya berdasarkan kesamaan hak.

Pasal 9 huruf (b) diakui sebagai subyek hukum.

4 Dengan di undangkannya UU Penyandang Disabilitas, penyandang disabilitas memiliki Hak yang sama dengan manusia yang normal. Hak-hak sebagaimana dimaksud tercantum di dalam Bab III tentang Hak Penyandang Disabilitas, dimana dalam Bab III tersebut terbagi kedalam bagian-bagian, bagian kesatu adalah Hak Umum yang di dalamnya adalah hak keadilan dan perlindungan hukum dan hak atas hidup secara mandiri dan dilibatkan dalam masyarakat. Bagian Kedua, yaitu hak hidup. Bagian ketiga, yaitu Hak bebas dari stigma meliputi hak bebas dari pelecehan, hinaan, label negatif terkait kondisi si penyandang disabilitas. Bagian keempat, yaitu Hak privasi berupa hak membina keluarga. Bagian kelima, yaitu Hak keadilan dan perlindungan hukum meliputi pengakuan sebagai subyek hukum sehingga memiliki kewenangan dalam menjalankan hak-haknya tersebut, dan hak-hak lainnya seperti hak politik, hak keagamaan, hak keolahragaan dan hak hidup secara mandiri dan dilibatkan dalam masyarakat yang terdapat di dalam Pasal 23 UU Penyandang Disabilitas. 
puan. Konsep dan kriteria kecakapan bertindak di dalam UU Penyandang Disabilitas sama dengan KUHPerdata, bahwa seseorang yang tidak cakap hukum adalah yang belum dewasa dan mereka yang dibawah pengampuan. Seorang yang di bawah pengampuan adalah "setiap orang yang telah berusia dewasa (21 tahun) tetapi berada dalam keadaan dungu (idiot), sakit otak atau mata gelap meskipun sewaktuwaktu cakap dalam mempergunakan pikirannya". ${ }^{5}$

Undang-Undang Nomor 4 tahun 1997 tentang Penyandang Cacat tidak mengenal istilah penyandang autisme, istilah penyandang autisme baru ada di dalam UU Penyandang Disabilitas dan istilah penyandang disabilitas autisme terdapat di dalam penjelasan Pasal 4 ayat (1) huruf (c) UU Penyandang Disabilitas, dimana autisme adalah bagian dari disabilitas mental. Pada penjelasan Pasal 4 ayat (1) huruf (c) UU Penyandang Disabilitas, seorang penyandang disabilitas mental adalah "seseorang yang mengalami gangguan kecerdasan (fungsi pikir), gangguan emosi dan juga perilaku, seperti skizofrenia, bipolar, depresi, anxietas, dan gangguan kepribadian dan disabilitas perkembangan yang mempengaruhi kemampuan interaksi sosial yang disebut autis dan hiperaktif. Menurut UU Penyandang Disabilitas, autis atau yang disebut autisme masuk kedalam kategori seseorang penyandang disabilitas mental, tetapi autisme bukan merupakan penyakit kejiwaan. Seseorang diketahui mengalami gangguan autisme, jika ia memiliki hambatan dalam tiga aspek, yaitu kualitas kemampuan interaksi sosial dan emosional, kualitas yang kurang dalam kemampuan berkomunikasi timbal balik, dan minat yang terbatas disertai gerakan berulang tanpa tujuan. ${ }^{6}$ Seseorang penyandang autisme berbeda dengan seorang yang menyandang difabel (menyandang cacat fisik maupun mental/lemah akal budi). Seseorang penyandang autisme adalah seseorang dengan karakteristik khusus yang berbeda dengan orang pada umumnya tanpa selalu menunjukan pada ketidakmampuan mental, emosi atau fisik. Asal kata autis adalah "autos" yang memiliki arti bahwa segala sesuatu yang mengarah pada diri sendiri. ${ }^{7}$ Jika seseorang penyandang disabilitas autis dikategorikan penyandang disabilitas mental, seorang penyandang disabilitas autis bisa saja dinyatakan tidak cakap di dalam hukum karena masuk kedalam kategori orang yang harus dibawah pengampuan karena dipersamakan dengan orang yang sakit mental (disabilitas mental). Berdasarkan latar belakang tersebut yang menjadi permasalahan dalam penelitian dalam tulisan ini adalah tentang konsep dan kriteria kecakapan bertindak bagi penyandang disabilitas autisme menurut persefektif hukum perdata Indonesia. Guna menjawab permasalahan tersebut penelitian dalam tulisan ini menggunakan metode penelitian hukum normatif yang dilakukan dengan studi pustaka (library research) yang bertujuan untuk mencari konsep dan kriteria kecakapan bertindak yang berlaku bagi penyandang disabilitas autisme menurut persefektif hukum perdata melalui dokumen peraturan perundangundangan dan bahan-bahan pustaka berupa bukubuku, makalah, artikel dan jurnal-jurnal ilmiah. Pendekatan yang digunakan adalah pendekatan perundang-undangan dan pendekatan konsep.

Pasal 443 KUHPerdata

6 Mohamad Sugiarmin, "Individu Dengan Gangguan Autisme", Jurnal Pendidikan Luar Biasa, Bandung: Universitas Pendidikan Indonesia, 2007, hlm. 3.

7 Dalam Kamus Lengkap Psikologi, autisme didefinisikan sebagai (1) cara berpikir yang dikendalikan oleh kebutuhan personal atau oleh diri sendiri, (2) menanggapi dunia berdasarkan penglihatan dan harapan sendiri, menolak realitas, dan (3) keasyikan ekstrim dengan pikiran dan fantasi sendiri, Chaplin, 2005, hlm. 46. 


\section{Pembahasan}

\subsection{Perbandingan antara Penyandang Disabilitas \\ Mental dengan Penyandang Disabilitas Autis}

Disabilitas mental kadang disebut retardasi mental, mempunyai artian "kelainan atau kelemahan jiwa dengan intelegensi yang kurang sejak masa perkembangan. Cacat mental merupakan istilah yang digunakan di Inggris, sementara di Amerika Serikat istilah yang digunakan adalah retardasi mental. Terkadang retardasi mental disebut juga oligofrenia yang berasal kata dari oligo yang berarti kurang dan fren yang berarti jiwa yang jika diartikan secara utuh disebut tuna mental. ${ }^{8}$ Retardasi mental adalah suatu keadaan dengan intelegensia yang kurang sejak masa perkembangan (sejak lahir atau sejak masa kanakkanak). Ditandai dengan perkembangan mental yang kurang secara keseluruhan yang ditandai dengan intelegensi yang terbelakang.

Menurut Carter $\mathrm{CH}$ (mengutif dari Toback $\mathrm{C}$ ), retardasi mental adalah suatu kondisi seseorang yang memiliki inlegensi rendah diikuti dengan kendala penyesuaian perilaku yang timbul pada masa perkembangan. Lebih jelas mengenai retardasi mental di uraikan oleh Melly Budiman yang menyatakan bahwa seorang menyandang retardasi mental apabila memenuhi kriteria :9

a. Fungsi intelektual umum dibawah normal, yaitu dibawah 70 .

b. Terdapat kendala dalam perilaku sosial, yaitu tingkah lakunya kekanak-kanakan dan tidak sesuai dengan umurnya.

c. Gejalanya timbul dalam masa perkembangan, yaitu dibawah usia 18 tahun dan jika gejala pada saat umur di atas 18 tahun maka tidak dapat disebut retardasi mental tetapi gangguan lain sesuai dengan gejala klinisnya.

UU Penyandang Disabilitas secara tegas memisahkan antara disabilitas mental dengan disabilitas intelektual. Di dalam penjelasan Pasal 4 huruf (b) UU Penyandang Disabilitas, disabilitas intelektual adalah "seseorang yang mengalami gangguan karena tingkat kecerdasan (fungsi pikir) di bawah rata-rata, antara lain lambat belajar, disabilitas grahita dan down syndrom". Terkadang terdapat kekeliruan dalam membedakan antara Penyandang disabilitas mental dengan intelektul yang mengakibatkan kesalahan penafsiran dalam memandang dan bahkan memperlakukan para penyandang disabilitas mental, intelektual dan autis. Sebagai contoh apakah seorang penyandang disabilitas mental sama dengan penyandang disabilitas intelektual, atau apakah seorang penyandang disabilitas mental dan disabilitas intelektual adalah sama dengan disabilitas autis.

Ragam penyandang disabilitas mental menurut penjelasan Pasal 4 ayat (1) huruf (c) UU Penyandang Disabilitas:

1. Skizofrenia berasal dari kata Chizein (terbelah) dan phren- (pikiran), yang berakar dari bahasa Yunani. Skizofrenia merupakan gangguan kejiwaan berat dan orang awam menyebut orang yang menderita Skizofrenia sebagai orang gila. Seorang penderita Skizofrenia mengalami halusinasi seperti mendengar suara-suara, mengalami delusi dan mengalami pikiran yang kacau yang menyebabkan sulit berkonsentrasi, gelisah, suka berteriak dan memaki tanpa alasan. Skizofrenia dapat di derita oleh siapa saja, laki-

8 Maramis WF, Retardasi Mental Dalam Catatan Ilmu Kedokteran Jiwa, Surabaya: Airlangga University Press, 1994, hlm. 385.

9 http://medicafarma.blogspot.com/2008/09/retardasi-mental.html. diakses pada 19 April 2018 
laki maupun perempuan. Seorang penderita Skizofrenia dapat di terapi meski tidak dapat disembuhkan secara total. Tujuan pengobatan secara terapi adalah untuk menurunkan gejala dan membantu si penderita memahami dan menerima akan keadaannya. ${ }^{10}$

2. Bipolar dapat juga disebut sebagai gangguan mental yang menyerang kondisi psikologis seseorang yang dapat dilihat dengan perubahan tingkah laku emosi yang sering berubah baik itu sewaktu-waktu atau pada saat waktu tertentu, perubahan emosi itu terjadi dengan sangat ekstrem kadang mengalami kebahagian berebih (mania) dan tiba-tiba bisa secara mendadak mengalami kesedihan (depresi) yang parah, atau dalam istilah medis disebut dengan manic depressive. ${ }^{11}$

3. Anxietas atau yang di dalam dunia kedokteran disebut anxiety disorder (gangguan kecemasan) adalah salah satu gangguan kejiwaan. Anxietas atau kecemasan sering dikenal dengan istilah perasaan cemas yang berlebih, perasaan bingung, was-was, bimbang. Dapat dikatakan Anxietas atau yang di dalam dunia kedokteran disebut anxiety disorder adalah perasaan panik yang berlebihan yang terjadi di dalam diri seseorang pengidapnya sehingga mempengaruhi kehidupannya secara baik secara pribadi dan soasial. ${ }^{12}$

4. Depresi disebut juga dengan istilah unipolar depression, yang adalah merupakan salah satu gangguan kejiwaan yang hampir mirip dengan bipolar namun sangat berbeda, dimana seorang yang depresi merasa dirinya nelangsa sedih berkelanjutan hingga berada pada titik terendahnya, dan amat putus asa hingga kehilangan motivasi dan semangat untuk menjalani aktivitas sehari-hari. Seorang yang mengalami depresi akan mengalami kesedihan yang berkelanjutan. Sementara seorang yang mengidap bipolar antara kesedihan dan kebahagian timbul bergantian, karenanya perubahan mood pada pengidap bipolar disebut mood swings. Sampai saat ini perbedaan perilaka antara seorang yang depresi dan seorang yang mengidap bipolar seriangkali sulit atau sukar untuk dibuat diagnosis secara resmi, karena gangguan mental ini sering menunjukkan gejala yang sama. ${ }^{13}$

5. Gangguan Kepribadian Di dalam dunia kedokteran biasa juga disebut personality disorder. Gangguan kepribadian juga merupakan gangguan kejiwaan yang mempengaruhi cara berfikir, perasaan dan perilaku. Seorang yang mengidap gangguan kepribadian sulit dalam bersosialisasi dengan keluarga dan lingkungan sekitarnya. Bagi penderita gangguan kepribadian sangatlah sulit untuk mengetahui perilaku yang dianggap normal dan yang tidak. ${ }^{14}$

6. Autisme merupakan suatu gangguan perkembangan pada anak yang sifatnya komplek dan berat, biasanya telah terlihat sebelum berumur 3 tahun, tidak mampu untuk berkomunikasi dan mengekspresikan perasaan maupun keinginannya. Akibatnya perilaku dan

10 Lihat https://id.wikipedia.org/wiki/Skizofrenia, dilihat pada tanggal 25 Januari 2018

11 Lihat https://id.wikipedia.org/wiki/Gangguan_bipolar, dilihat pada tanggal 25 Januari 2018.

12 Lihat https://id.wikipedia.org/wiki/Anxietas, dilihat pada tanggal 25 Januari 2018

13 Lihat https://id.wikipedia.org/wiki/Depresi_(psikologi), dilihat pada tanggal 25 Januari 2018

14 Lihat, https://www.alodokter.com/gangguan-kepribadian, dilihat pada tanggal 25 Januari 2018 
hubungannya dengan orang lain menjadi terganggu, sehingga keadaan ini akan sangat mempengaruhi perkembangan anak selanjutnya. ${ }^{15}$

Penyandang disabilitas autis dalam UU Penyandang Disabilitas masuk kedalam salah satu dari kategori disabilitas mental. Padahal penyandang autis bukanlah penyandang disabilitas mental pada umumnya yang terganggu fungsi pikir, emosi, dan perilaku. Walaupun untuk beberapa penyandang disabilitas autis ada yang mengarah kepada disabilitas intelektul dan/atau mengarah kepada disabilitas mental, namun tidak semua penyandang disabilitas autis seperti itu. Autis adalah disabilitas perkembangan yang mempengaruhi kemampuan interaksi sosial bagi para penyandangnya dan lebih dipersamakan dengan sikap yang hiperaktif. Namun penderita autis di dalam UU Penyandang Disabilitas dipersamakan dengan orang yang menderita sakit mental sebagaimana halnya penyandang skizofrenia, penyandang bipolar, penyandang depresi, penyandang anxietas, dan penyandang gangguan kepribadian.

Secara definisi yang mudah dimengerti, autisme adalah suatu gangguan pada otak yang mengakibatkan hilangnya atau berkurangnya kemampuan seseorang untuk berkomunikasi, berhubungan dengan sesama dan memberi tanggapan terhadap lingkungannya. ${ }^{16}$ Pada umumnya autisme adalah gangguan perkembangan yang diderita dan terjadi pada anak, karena gejala-gejala autisme menunjukkan penyimpangan perkembangan yang normal pada usia dini. Wealt Healt Organization (WHO) telah merumuskan diagnosa autisme yang dikenal dengan sebutan International Clasification of Diseases
(ICD-10). Rumusan diagnostik lain yang juga dipakai di seluruh dunia (yang dibuat oleh grup psikiatri dari Amerika) tentang panduan diagnosis autisme adalah Diagnostic and Statistical Manual (DSM-IV). Rumusan ICD-10 maupun DSM-IV pada dasarnya adalah sama. Kriteria DSM-IV untuk autisme pada masa anak-anak adalah minimal memiliki enam gejala dengan sedikitnya dua gejala sebagaimana yang disebutkan dibawah ini: 17

(1). Gangguan dalam interaksi sosial, yaitu :

a. tidak dapat berinteraksi secara sosial, ekspresi mimik muka yang datar (kurang hidup), gerak-gerik yang kurang tertuju.

b. tidak dapat bermain dengan teman yang berusia sebaya denganya.

c. tidak memiliki empati (merasakan apa yang dirasakan oleh orang lain).

d. tidak peka akan lingkungan sekitar (kurangnya hubungan sosial) dan tidak peka akan respon dari lawan bicaranya (emosional yang timbal balik).

(2). Gangguan dalam bidang komunikasi :

a. kemampuan berbicara yang terlambat atau bahkan sama sekali tidak berkembang.

b. Jika bisa bicara (komunikasi), bicaranya tidak dipergunakan untuk berkomunikasi

c. Berbicara dengan menggunakan bahasa yang aneh (tidak dapat dimengerti) dan sering memakai kalimat yang berulang

d. Ketika bermain kurang variatif dan imajinatif dan kurang tidak dapat meniru.

(3). Melakukan sesuatu secara berulang-ulang dalam perilaku :

15 S.A. Nugraheni, Menguak Belantara Autisme, Buletin Psikologi Volume 20, Fakultas Psikologi Universitas Gajah Mada, No. $102,2012$.

16 Hartono, B., Aspek neurologik Autisme Infantil. Seminar \& Work-shop on Fragile-X Mental Retardation, Autism and Related Disorders. Semarang: Badan Penerbit Universitas Diponegoro. 2002.

17 S.A. Nugraheni, Loc., Cit, hlm 12. 
a. Berminat pada suatu objek atau beberapa objek dengan cara yang khas dan berlebihlebihan.

b. Terpaku pada suatu kegiatan yang dilakukan secara ritualistik dan/atau rutinitas.

c. Melakukan gerakan yang aneh dan khas dan dilakukan secara diulang-ulang.

d. Seringkali sangat terpukau (takjub) pada bagian-bagian benda.

Seorang penyandang disabilitas terdiri dari berbagai macam tingkatan begitu juga penyandang autisme, ada yang parah dan ada yang tidak. Karena itu dapatkah semua penyandang autis dipukul rata lemah akal budinya dan tidak cakap di dalam hukum, sehingga dia tidak dapat bertindak dan memiliki tanggung jawab terhadap dirinya sendiri dan perlu diwakilkan karena kondisinya memaksa demikian (dibawah pengampuan). Sudut pandang dalam melihat perilaku seorang penyandang autis tidak dapat hanya dilihat dari ketidakmampuannya dalam hal tertentu, sementara dalam hal tertentu yang lain diabaikan, padahal seorang penyandang autis itu bisa berprestasi ${ }^{18}$ dan melahirkan suatu karya yang besar dan diakui sebagaimana manusia normal lainnya. Banyak pengidap autisme dapat berkarya dan karyanya diakui oleh dunia. Lalu ketika seorang pengidap autis dinyatakan dia mampu hidup mandiri tanpa bantuan orang lain apakah dia dapat bertindak secara hukum atau masih tetap distigmakan sebagai seorang yang cacat. Di dalam hukum seorang yang dianggap tidak cakap diartikan dalam dua lingkup, yaitu sakit ingatan (gila/tidak waras) dan dibawah pengampuan (boros, lemah akal budi, sakit ingatan). Lalu dimana posisi seorang pengidap autis itu berada, apakah orang yang dinyatakan hilang ingatan atau seorang yang lemah akal budi sehingga perlu pengampuan dan dikategorikan subyek hukum yang tidak cakap.

Ketika seseorang dianggap tidak cakap hukum tentunya akan membawa dampak bagi kehidupan orang tersebut. Dampaknya adalah bahwa seorang penyandang autis secara langsung ataupun tidak langsung tidak dapat melakukan perbuatan hukum semisal membuat suatu perjanjian. Meskipun dengan menempatkan seorang penyandang autisme di bawah pengampuan adalah merupakan salah satu dari perlindungan hukum yang ada dan di atur di dalam KUHPerdata, namun tetap bukanlah suatu jalan terbaik bagi penyandang disabilitas autisme karena di dalam menjalankan kewenangannya harus diwakili oleh orang lain (curator), lagi pula tidak semua penyandang disabilitas autis itu memiliki intelektual dibawah ratarata, dari sisi intelektualitas sebanyak $40 \%$ autisme menderita retardasi mental sedang, berat dan sangat berat, sebanyak $30 \%$ dengan retardasi mental ringan dan sisanya memiliki fungsi intelektual yang normal. Oleh karenanya penempatan disabilitas autis ke dalam disabilitas mental mengakibatkan penafsiran, bahwa semua penyandang disabilitas autis adalah orang yang lemah akal atau mengalami hambatan mental sehingga harus ditaruh atau dianggap orang yang sewaktu-waktu harus ditaruh dibawah pengampuan. Bagi penyandang disabilas autis yang tidak mengalami ciri-ciri penyandang disabilitas intelektual dan mental, seorang penyandang disabilas autis adalah sama dengan orang

18 https://www.rappler.com/indonesia/berita/174050 : Musa Izzanardi Wijanarko mendadak jadi pemberitaan di berbagai media massa. Publik dibuat tercengang dengan prestasi bocah 14 tahun ini Bagaimana tidak, di usianya yang masih belia, Izzan, demikian dia biasa disapa, berhasil menembus seleksi masuk perguruan tinggi terkemuka, Institut Teknologi Bandung (ITB). Tak tanggung-tanggung, dia diterima di fakultas yang bisa dikatakan sulit, yakni Fakultas Matematika dan IImu Pengetahuan Alam. Yang menambah kagum, prestasi itu diperoleh dengan kondisi dirinya sebagai anak berkebutuhan khusus. Izzan sempat mendapat berbagai diagnosis oleh psikolog yang menanganinya, mulai dari hiperaktif, asperger syndrome, austism spectrum disorder, gangguan sensori integrasi, dan gangguan mobilitas. Namun secara kecerdasan, Izzan melampaui teman-teman sebayanya. Skor IQ Izzan berdasarkan skala Wechsler mencapai 142, yang berarti sangat superior. Diakses pada 01 Juni 2018 Jam 13.09 WIB. 
normal pada umumnya dan bahkan memiliki intelegensia yang lebih daripada orang yang normal dalam bidang tertentu. Dengan menyamaratakan penyandang disabilitas autis dengan disabilitas mental mengakibatkan seorang penyandang autis dapat dan/atau harus berada di bawah pengampuan. Pengampuan adalah merupakan salah satu dari perlindungan hukum yang ada dan di atur di dalam KUHPerdata, namun tetap bukanlah suatu jalan terbaik bagi si penyandang disabilitas autis karena di dalam menjalankan kewenangannya harus diwakili oleh orang lain (curator). Seandainya semua penyandang disabilitas autis harus ditaruh di dalam suatu pengampuan, karena ditafsirkannya Pasal 4 huruf (c) UU Penyandang Disabilitas secara kaku, padahal dia layak dan cakap dan tidak harus ditaruh dibawah pengampuan (memang seharusnya dikatakan cakap secara medis), adalah sama dengan mengatakan bahwa perbuatan yang dilakukan adalah bukan atau tidak karena kesadaran diri dan tidak dikehendaki secara bebas (actus hominis), ${ }^{19}$ padahal manusia adalah tuan untuk dirinya sendiri, bahwa setiap perbuatan yang dilakukan adalah haruslah dengan penuh kesadaran diri dan kehendak bebas. Jika manusia menjadi tuan atas perbuatannya, ia dapat mengarahkan dan mempertanggungjawabkan perbuatannya itu dengan bebas (actus humanus). ${ }^{20}$

\subsection{Konsep dan Kriteria Kecakapan Bertindak}

Defenisi tentang kecakapan tidak diuraikan secara tegas di dalam KUHPerdata. Tidak ada klasifikasi tentang seorang yang cakap dalam hukum, yang ada hanya tentang ketidakcakapan. Konsep dan kriteria kecakapan bertindak tertuang di dalam Buku III Pasal 1330 KUHPerdata, dikatakan bahwa "yang tak cakap membuat persetujuan adalah mereka yang belum dewasa dan dibawah pengampuan, serta orangorang perempuan yang terikat perkawinan". ${ }^{21}$ Parameter yang digunakan untuk menilai konsep dan kriteria cakap adalah kebalikan dari apa yang dikatakan Pasal 1330 KUPerdata, bahwa seorang yang cakap adalah yang dapat membuat persetujuan dengan kriteria telah dewasa (berdasarkan umurnya) dan tidak ditaruh di bawah pengampuan. Dengan begitu dapat disimpulkan bahwa kecakapan dalam bertindak adalah kecakapan dalam membuat suatu perbuatan hukum persetujuan (perjanjian) dengan syarat umur yang dewasa dan tidak ditaruh dibawah pengampuan.

Pada prinsipnya, suatu perjanjian adalah suatu perbuatan hukum yang di dalamnya memunculkan hak dan kewajiban bagi para pihak yang membuatnya. Oleh karena itu pembuat undang-undang secara tidak langsung menyatakan bahwa setiap orang yang cakap (bekwaam) dan berwenang (bevoedg) untuk melakukan perbuatan hukum adalah orang yang cakap dalam membuat suatu perjanjian.

Kecakapan dalam bertindak atau yang dalam bahasa Belanda disebut sebagai handelingsbekwaamheit adalah kewenangan yang dipunyai atau dimiliki oleh orang pada umumnya, untuk melakukan suatu perbuatan hukum pada umumnya. Contoh perbuatan hukum dimaksud salah satunya adalah membuat suatu perjanjian, dimana untuk membuat suatu perjanjian baik dibuat di bawah tangan ataupun dihadapan Notaris orang tersebut haruslah berusia dewasa dan tidak dalam keadaan di bawah pengawasan (karena perilaku

19 Sumaryono, Etika dan Hukum Relevansi Hukum Kodrat Thomas Aquinas, Jakarta: Kanisius, 2006, hlm. 254.

20 Ibid, hlm. 254

21 ketentuan Pasal 1330 KUHPerdata telah dihapus sebagian berdasarkan Surat Edaran Mahkamah Agung Nomor 3 tahun 1963, tanggal 5 September 1963 yang mencabut beberapa pasal KUHPerdata di antaranya Pasal 108 dan 110 KUHPerdata, sejak dicabutnya pasal 108 dan 110 KUHPerdata oleh Surat Edaran Mahkamah Agung di atas maka istri adalah cakap bertindak dalam hukum. 
yang tidak stabil) dan bukan pula orang-orang yang dilarang menurut undang-undang dalam membuat perjanjian.

Menurut Subekti, cakap adalah mengerti akan sesuatu yang dilakukan serta mengetahui dampak dari perbuatan yang dilakukannya. Dengan kata lain, sudah dapat mengendalikan apa yang diperbuatnya serta mampu mempertanggung jawabkannya. Satrio menulis kecakapan melakukan tindakan hukum dalam hukum perdata, dikaitkan dengan unsur kedewasaan dan hal itu secara tidak langsung ada kaitannya dengan unsur umur, akan tetapi dari ketentuan-ketentuan yang ada dalam KUHPerdata, antara lain Pasal 307 jo Pasal 308 KUHPerdata, Pasal 383 KUHPerdata, maupun Pasal 47 KUHPerdata dan Pasal 50 UU No. 1 Tahun 1974 tentang Perkawinan, Pasal 1330 dan Pasal 1446 KUHPerdata, bisa disimpulkan, bahwa pada asasnya yang dapat melakukan tindakan hukum secara sah dengan akibat hukum yang sempurna adalah mereka yang telah dewasa. ${ }^{22}$ Secara singkat, kecakapan bertindak bergantung dari kedewasaan yang dibatasi umur. Namun demikian, ada faktor lain, seperti status menikah, yang bisa mempengaruhi kecakapan seseorang. Menurut R. Setiawan, seseorang adalah tidak cakap apabila ia pada umumnya berdasarkan ketentuan Undang-Undang tidak mampu membuat sendiri perjanjian-perjanjian dengan akibat-akibat hukum yang sempurna. Dengan pengertian ketidakcakapan yang tersebut di atas, maka kecakapan seseorang dalam membuat perjanjian dapat diartikan sebagai kemampuan orang tersebut dalam membuat dan melaksanakan perjanjian sendiri dengan segala akibat hukumnya, dengan batasan umur lebih dari 18 tahun yang dianggap sudah dewasa.

Istilah "kecakapan" dan "kewenangan" dalam hukum mempunyai arti dan peranan yang sangat berbeda. Kewenangan Hukum (rechtsbevoegdheid) adalah kewenangan untuk menjadi pendukung (mempunyai) hak dan kewajiban dalam hukum. ${ }^{23}$ Kewenangan bertindak (handelingsbevoegdheid) adalah kewenangan khusus, yang dipunyai oleh persoon tertentu, untuk melakukan tindakan hukum (atau tindakan-tindakan hukum) tertentu. ${ }^{24}$ Konsep tentang kecakapan dan kewenangan bertindak dalam hukum dipengaruhi faktor-faktor yang mempengaruhi kecakapan. Faktor-faktor yang mempengaruhi tersebut adalah :

1. Faktor psikologis adalah faktor yang berhubungan dengan kondisi rohani dan mental.

2. Faktor fisiologis adalah faktor yang berhubungan dengan kondisi fisik atau keadaan jasmani, dan

3. Faktor lingkungan adalah faktor yang berpengaruh pada kehidupan seseorang dalam proses perkembangannya. Faktor lingkungan dibagi menjadi 3 yaitu yang bersifat fisik, kimiawi dan biologis.

Bahwa setiap orang selaku subyek hukum memiliki hak dan kewajiban dalam melakukan perbuatan hukum, namun tidak semua dapat dengan leluasa menjalankan hak dan kewajibannya. ${ }^{25}$ Secara

22 Bertrand A. Hasibuan, "Problematika Kedewasaan Bertindak di dalam Hukum (Studi pada Praktik Notaris di Kota Medan)", Tesis, Universitas Sumatera Utara, 2006, hlm. 36

23 Subekti, Pokok-Pokok Hukum Perdata, cetakan XXXIV, Jakarta: PT. Intermasa, 2010, hlm. 20

24 J. Satrio, Hukum Pribadi, Bagian I, Persoon Alamiah, Cetakan I, Bandung: Citra Aditya Bakti, 1999, hlm. 56.

25 Walaupun menurut hukum tiap orang tanpa kecuali dapat memiliki hak, tetapi di dalam hukum tidak semua orang diperbolehkan bertindak sendiri untuk melaksanakan hak-haknya. Karena Kewenangan bertindak menurut hukum dibedakan menjadi dua, yaitu kemampuan berbuat dan berhak berbuat. Kemampuan berbuat adalah karena memenuhi syarat secara hukum, yaitu cakap yang dipersamakan dengan dewasa karena memenuhi syarat sebagaimana undang-undang, pengecualiannya adalah jika si dewasa berada dalam sakit ingatan atau gila dan tidak mampu mengurus dirinya sendiri karena boros, maka akan disamakan dengan orang yang belum dewasa dan oleh hukum akan dinyatakan tidak cakap. Sementara itu berhak berbuat adalah diakui oleh hukum walaupun tidak memenuhi syarat hukum (bevoeg) seperti seorang perempuan yang berumur 16 tahun dapat melangsungkan suatu pernikahan walaupun mereka belum dewasa, tetapi hukum mengakui perbuatan tersebut karena diatur dalam Pasal 7 ayat 1 UU Perkawinan. Lihat I Ketut Oka Setiawan, Hukum Perorangan Dan Kebendaan, Jakarta: Sinar Grafika, 2016, hlm 30. 
prinsip undang-undang menganggap setiap orang yang telah cukup dewasa dapat melakukan suatu perbuatan hukum. Dan mengenai batasan usia dewasa tersebar di beberapa undang-undang dan juga berbeda-beda, salah satu dari sekian undang-undang yang mencantumkan usia dewasa adalah sebagaimana di bawah ini :

Merujuk kepada batasan umur tersebut di atas, umur dalam peraturan perundang-undanganan yang digunakan untuk menentukan kewenangan bertindak sangatlah bervariasi. Umur yang digunakan untuk menentukan kecakapan dalam arti luas sangat dipengaruhi oleh terminologi "dewasa". ${ }^{26}$

Mengenai ketidakcakapan bertindak juga di atur di dalam UU Penyandang Diabilitas, tepatnya di dalam penjelasan Pasal 32, dikatakan bahwa yang dimaksud dengan "tidak cakap" antara lain orang yang belum dewasa dan/atau dibawah pengampuan. Konsep dan kriteria kecakapan bertindak sebagaimana penjelasan Pasal 32 UU Penyandang Disabilitas adalah sama dengan yang terdapat di dalam KUHPerdata, dimulai dari apa yang dimaksud dengan tidak cakap yang kemudian ditafsirkan bahwa kebalikan dari kriteria yang dinyatakan tidak cakap adalah kriteria dari kecakapan bertindak. Oleh karenanya untuk dapat dikatakan cakapnya seorang subyek hukum, baik di dalam KUHPerdata dan UU Penyandang Diabilitas harus memenuhi dua kriteria :

Tabel. 2.1.

Batasan Usia Dewasa

\begin{tabular}{|l|c|}
\hline \multicolumn{1}{|c|}{ Dasar Hukum } & Pasal \\
\hline KUHPerdata (Burgerlijk Wetboek) & $\begin{array}{c}\text { Pasal 330 } \\
\mathbf{2 1} \text { Tahun }\end{array}$ \\
\hline UU No. 1 Tahun 1974 tentang Perkawinan & $\begin{array}{c}\text { Pasal } 47 \\
\mathbf{1 8} \text { tahun. }\end{array}$ \\
\hline UU No. 13 Tahun 2003 tentang Ketenagakerjaan & $\begin{array}{c}\text { Pasal } 1 \text { angka 26 } \\
18 \text { tahun }\end{array}$ \\
\hline UU No. 12 Tahun 1995 tentang Pemasyarakatan & $\begin{array}{c}\text { Pasal } 1 \text { angka } 8 \\
18 \text { tahun }\end{array}$ \\
\hline UU No. 2 Tahun 2014 tentang Jabatan Notaris & $\begin{array}{c}\text { Pasal 39 ayat (1) huruf (a) } \\
18 \text { tahun }\end{array}$ \\
\hline UU No. 39 Tahun 1999 tentang Hak Asasi Manusia & $\begin{array}{c}\text { Pasal 1 angka 5 } \\
18 \text { tahun }\end{array}$ \\
\hline UU No. 23 Tahun 2002 tentang Perlindungan Anak & $\begin{array}{c}\text { Pasal } 1 \text { ayat (1) } \\
\mathbf{1 8} \text { (delapan belas) tahun } \\
\text { Pasal 1 angka 5 } \\
\text { (delapan belas) tahun }\end{array}$ \\
\hline $\begin{array}{l}\text { UU No. 21 Tahun 2007 tentang Pemberantasan Tindak Pidana } \\
\text { Perdagangan Orang }\end{array}$ &
\end{tabular}

1. Usia

2. Tidak ditarush dibawah pengampuan.

Persamaan konsep kecakapan bertindak sebagaimana UU Penyandang disabilitas dan KUHPerdata menimbulkan kontradiksi dengan semangat UU Penyandang Disabilitas terlebih dengan kata lain autis adalah berbeda dengan disabili-

ditempatkannya seorang penyandang disabilitas autisme sebagai penyandang disabilitas mental. Dalam penjelasan Pasal 4 ayat (1) huruf (c) dikatakan bahwa autis adalah disabilitas perkembangan yang berpengaruh pada kemampuan interaksi sosial,

26 Pasal 1330 KUHPerdata tidak menentukan umur tertentu, tetapi merujuk pada terminologi dewasa yang oleh Pasal KUHPerdata ditetapkan bahwa dewasa adalah yang telah mencapai umur tertentu (21 tahun). 
tas mental sebagaimana skizofrenia, bipolar, depresi, anxietas, dan gangguan kepribadian yang mengalami gangguan jiwa atau bisa disebut gila. Dengan menempatkan autisme ke dalam disabilitas mental dapat menyebabkan seorang autis adalah seorang yang harus berada dibawah pengampuan.

\subsection{Analisis Yuridis Konsep dan Kriteria Kecakapan Bertindak bagi Penyandang Disabilitas Autis}

Apeldoon menyatakan bahwa subyek hukum adalah segala sesuatu yang memiliki atau mempunyai kewenangan untuk melakukan suatu perbuatan hukum yang dalam istilah bahasa Belanda disebut dengan persoonlijkheid (kewenangan hukum). Namun dalam menjalankan kewenangan hukum tersebut haruslah didukung dengan kecakapan sehingga dapat menjadi pendukung subyek hukum yang diberikan oleh hukum obyektif.27 Kewenangan bertindak (handelingsbevoegdheid) adalah kewenangan khusus, yang dipunyai oleh persoon tertentu, untuk melakukan tindakan hukum (atau tindakan-tindakan hukum) tertentu. ${ }^{28}$ Jika seorang dinyatakan cakap bertindak menurut hukum, hukum juga menentukan seorang yang dianggap tidak cakap bertindak menurut hukum.

Umur adalah salah satu parameter yang digunakan sebagai syarat bagi subjek hukum untuk memiliki kecakapan bertindak. Salah satu bentuk kewenangan bertindak berdasarkan batasan umur adalah kewenangan untuk melakukan perbuatan hukum perkawinan, sebagaimana termaktub dalam Pasal 7 UU No.1 Tahun 1974 tentang Perkawinan, yang menyatakan "Perkawinan hanya diizinkan jika pihak pria sudah mencapai 19 tahun dan pihak wanita mencapai umur 16 tahun". Meskipun memiliki batasan ukuran yang sama, yaitu umur, kewenangan bertindak tidak dapat disamakan dengan kecakapan. Dalam beberapa kondisi, seseorang yang mencapai umur tertentu memiliki kewenangan bertindak dan juga memiliki kecakapan. Namun tidak berarti, bahwa setiap yang memiliki kewenangan bertindak pasti cakap dalam hukum, atau setiap yang cakap dalam hukum pasti memiliki kewenangan bertindak. Dalam praktik tidak mudah membuat batas antara kewenangan bertindak dan kecakapan, meski keduanya memilki ranahnya sendiri. Di dalam Pasal 9 huruf (b) UU Penyandang Disabilitas seorang penyandang disabilitas diakui sebagai subyek hukum. Dengan diakuinya seorang penyandang disabilitas sebagai subyek hukum sebagaimana yang dinyatakan dalam UU Penyandang Disabilitas, maka setiap orang yang menyandang disabilitas adalah subyek hukum yang dapat bertindak secara hukum kecuali yang oleh Undang-Undang dikatakan tidak cakap karena batasan usia dan berada di bawah pengampuan karena dalam keadaan sakit ingatan atau gila dan tidak mampu mengurus dirinya sendiri karena boros. Yang membedakan antara subyek hukum yang cakap dan subyek hukum yang tidak cakap adalah berkaitan dengan pemenuhan tanggung jawab. Bahwa subyek hukum yang tidak cakap tidak dapat dikenakan tanggung jawab secara langsung namun melalui pengampu atau curatele nya.

Selain usia, Pasal 1330 KUHPerdata menyebutkan bahwa yang tak cakap membuat persetujuan adalah adalah orang-orang yang ditaruh di bawah pengampuan. Satrio mengatakan bahwa pengampuan tak pernah terjadi demi hukum, tetapi

27 L.J.van Apeldoorn, Pengantar Ilmu Hukum, Jakarta: Pradnya Paramita, 1983, hlm. 203

28 J. Satrio, Hukum Pribadi, Bagian I, Persoon Alamiah, Cetakan I, Bandung: Citra Aditya Bakti, 1999, hlm. 56. 
didasarkan atas permohonan (Pasal 434 s/d 445 KUHPerdata) dan ia baru mulai berlaku sejak ada ketetapan pengadilan mengenai hal itu (pasal 446 KUHPerdata). ${ }^{29}$ Beliau juga mengatakan bahwa Undang-Undang berangkat dari anggapan, bahwa semua orang yang terganggu jiwanya, lemah akalnya dan pemboros berada dibawah pengampuan (atau paling tidak suatu ketika akan berada dibawah pengampuan), ${ }^{30}$ sedang bagi orang-orang yang terganggu jiwanya, lemah akalnya tetapi belum mendapatkan penetapan pengampuan tidak diatur oleh undang-undang. ${ }^{31}$ Dari cara pengaturan yang seperti itu Satrio menduga bahwa undang-undang mengganggap semua orang yang berada dalam keadaan tersebut di atas harus berada di bawah pengampuan atau suatu ketika akan berada di bawah pengampuan dan orang yang ditaruh dibawah pengampuan dapat terjadi atas dasar : 32

a. Gila (sakit otak), dungu (oonoozelheid), mata gelap (razernij)

b. Lemah akal (zwakheid van vermogens)

c. pemborosan
Di dalam UU Penyandang Disabilitas terdapat ragam penyandang disabilitas diantaranya, yaitu disabilitas fisik, intelektual, mental dan disabilitas sensorik. Penyandang autisme adalah seorang yang dianggap penyandang disabilitas mental (menurut UU Penyandang Disabilitas). Dengan dimasukannya autis ke dalam kategori penyandang disabilitas mental tentunya menimbulkan kesesatan penafsiran apakah seorang autis sama dengan penyandang disabilitas mental pada umumnya dan bisa dianggap seorang yang terganggu jiwanya padahal autis yang di dalam dunia kedokteran disebut sebagai Autism Spectrum Disorder (ASD), adalah gangguan perkembangan saraf yang terjadi pada otak yang menyebabkan otak tidak dapat berfungsi secara normal, ${ }^{33}$ namun bukanlah merupakan sakit otak. Sangat sulit untuk dapat menentukan kecakapan secara nyata yang melekat pada seorang individu, mengingat kondisi masingmasing individu berbeda, dan juga dipengaruhi oleh faktor-faktor psikologis, fisiologis, dan juga dipengaruhi oleh faktor lingkungan. Namun demikian, guna memberikan kepastian hukum, haruslah ditetapkan suatu standar yang digunakan untuk menilai batasan

29 Satrio, J, Hukum Perjanjian, Bandung: Citra Aditya Bakti, 1992, hlm. 282

$30 \quad$ Ibid. hlm. 282

31 Ibid. hlm. 283

32 Ibid. hlm. 283

3350 (limapuluh persen) autisme disebabkan oleh kelainan kromosom saat penyusunan otak. Pada anak penyandang autisme, wilayah otak yang disebut frontal cortex yang terdiri atas prefrontal cortex dan temporal cortex tidak dapat berfungsi secara sempurna. Kelainan ini menyebabkan otak tidak dapat memberi perintah terkait ekspresi, emosi, dan interaksi sosial. Perintah tersebut ada di bagian frontal cortex. Frontal cortex memiliki bagian prefrontal cortex yang merupakan pusat kognitif. Bagian ini memiliki fungsi eksekutif terkait emosi yang ditampilkan. Bagian ini juga berperan dalam penilaian, kretivitas, dan berbicara. Sedangkan bagiak lobus temporal pada otak menjalankan fungsi mendengar, penguasaan bahasa, dan interprestasi suara. Otak anak penyandang autisme juga bermasalah pada wilayah fusi form. Bagian ini berfungsi untuk mengenali wajah. Pada penyandang autis fusi form tidak merespon ketika ditunjukkan gambar wajah. "Bagian fusi form ada pada anak autis, namun tidak bekerja. Otak seseorang dengan dan tanpa autis juga berbeda secara kimiawi. Hal ini dibuktikan penelitian yang dilakukan Prof. Daniel Geschwind dari University of California, Los Angeles. Penelitian itu menunjukkan, bagian prefrontal dan temporal pada autis menghasilkan protein yang sama. Pola ini, menurut Geschwind tampak pada penderita autis. Padahal pada otak tanpa autis, tiap bagian dikendalikan susunan gen yang berbeda. Susunan gen tersebut akan menghasilkan protein yang berbeda. Namun hal tersebut tidak ditemukan pada penyandang autisme. Penelitian yang digagas Geschwind diadakan di Inggris, Amerika Serikat, dan Kanada. Sampel penelitian adalah 19 otak dengan dan 17 otak tanpa autis. Dari hasil perbandingan terungkap, ada sekitar 209 gen terkait cara kerja dan komunikasi sel otak bekerja dalam tingkat yang lebih rendah dibanding yang tanpa autis. Sementara 235 gen yang berhubungan dengan daya tahan dan respon luka diekspresikan dengan lebih kuat. Riset lainnya menunjukkan, otak penyandang autisme juga memiliki badan sel saraf (neuron) lebih banyak 67 persen di bagian prefrontal kortex, dibanding yang tanpa autis. Jumlah total sel neuron penyandang autisme adalah sekitar 1,9 milyar, sedangkan non autisme 1,7 milyar. Akibatnya, bobot otak penyandang autis cenderung lebih berat. Hal ini mengindikasikan adanya keadaan abnormal. Bisa potensi koneksi yang meningkat, atau justru sebaliknya," kata peneliti Dr. Eric Courchesne, Director of the National Institute of Health-University of California-San Diego School of Medicine Autism Center of Excellence. Penelitian dilakukan pada tujuh otak anak tanpa autis, dan enam otak anak dengan autis. Lihat https://klinikautis.com/2011/10/24/gangguan-strukstur-dan-fungsi-otak-penderitaautism/, diakses pada tanggal 26 Januari 2018, jam 17.48 WIB. 
kecakapan khususnya bagi penyandang disabilitas autisme pasca diundangkannya UU Penyandang Disabilitas. Apa yang disebut cakap menurut KUHPerdata adalah lawan atau kebalikan dari tidak cakap sebagaimana yang ditentukan di dalam Pasal 1330 KUHPerdata.

UU Penyandang Disabilitas juga tidak mendefenisikan kecakapan suatu subyek hukum, sama halnya dengan KUHPerdata. Kedua nya sama-sama menentukan kecakapan itu berangkat dari ketidakcakapan. Penjelasan Pasal 32 UU Penyandang Disabilitas adalah penafsiran dari Pasal 1330 KUHPerdata, yang menyatakan bahwa yang dimaksud dengan "tidak cakap" adalah orang yang belum dewasa dan/atau di bawah pengampuan. Dengan kata lain, seorang yang cakap adalah orang yang dewasa dan tidak di bawah pengampuan. Suatu peraturan idealnya bertujuan untuk memberikan jaminan kepastian hukum.

Secara sekilas apa yang di atur mengenai ketidakcakapan di dalam KUHPerdata telah memberikan jaminan kepastian hukum sehingga digunakan pula di dalam penjelasan Pasal 32 UU Penyandang Disabilitas. Namun pengertian, konsep dan kriteria yang sama tersebut telah memunculkan ketidakpastian yang baru di tengah kepastian hukum dan keadilan yang selama ini dicari dan diimpikan oleh para penyandang disabilitas.

Satjipto Rahardjo mengatakan bahwa "Hukum itu bukan hanya bangunan peraturan, melainkan juga bangunan ide, kultur, dan cita-cita". Beliau juga mengatakan "bahwa pemikiran hukum perlu kembali pada filosofis dasarnya, yaitu hukum untuk manusia". Artinya hukum bertugas melayani manusia, bukan sebaliknya. Oleh karena itu, hukum itu bukan merupakan institusi yang lepas dari kepentingan manusia. Mutu hukum ditentukan oleh kemampuannya untuk mengabdi pada kesejahteraan manusia. Pemikiran yang demikian oleh Profesor Satjipto Rahardjo disebut hukum progresif yang menganut "ideologi" : Hukum yang pro-keadilan dan Hukum yang Pro-rakyat. Dalam logika beliau revitalisasi hukum dilakukan setiap kali. Bagi hukum progresif, proses perubahan tidak lagi berpusat pada peraturan, tetapi pada kreativitas pelaku hukum mengaktualisasikan hukum dalam ruang dan waktu yang tepat. Dengan tetap digunakannya konsep dan kriteria ketidakcakapan yang sama dengan konsep dan kriteria ketidakcakapan yang telah berlaku selama ini, ${ }^{34}$ maka menimbulkan suatu pertanyaan, apakah konsep dan kriteria kecakapan bertindak yang selama ini digunakan telah sesuai dengan perkembangan jaman ditengah dinamisnya hukum itu. Konsep kecakapan telah digunakan hampir kurang lebih 170 (seratus tujuh puluh) tahun lamanya dan apakah konsep ini bisa tetap bertahan atau diperlukan pembaharuan karena jaman dan ilmu pengetahun yang bersinggungan dengan ilmu hukum mulai beragam.

Gustav Radbruch mengemukakan tentang kepastian hukum yang didasari bahwa kepastian hukum adalah kepastian tentang hukum itu sendiri. 4 (empat) hal makna kepastian hukum diantaranya adalah "bahwa hukum itu adalah kenyataan karena berdasarkan pada fakta (tatsachen) dan fakta itu harus dirumuskan dengan cara yang sejelas mungkin guna menghindari kekeliruan dalam memaknainya supaya bisa dilaksanakan secara mudah". Suatu peraturan perundang-undangan dibuat untuk mengatur segala sesuatu, aturan tersebut adalah batasan apa yang

34 KUHPerdata di Indonesia (dahulu bernama Hindia Belanda) berlaku melalui asas konkordansi yang dinyatakan berlaku mulai pada 1 Mei 1848, namun baru pada tanggal 1 Oktober 1917 melalui S. 1917 - 12 bagi golongan bumiputera dan golongan timur asing yang dengan sukarela menundukan dirinya kepada BW maka berlaku pula kepada dirinya. Pada tahun 1963 beberapa pasal di dalam KUHPerdata yang dianggap tidak sesuai, berdasarkan SEMA Nomor 3 tahun 1963 telah dihapus. Jadi jika mengacu kepada sejarah berlakunya KUHPerdata pertama kalinya di Indonesia sampai dengan saat ini adalah bahwa KUHPerdata telah digunakan sejak 170 tahun yang lalu. 
boleh dan tidak boleh dilakukan dan apa akibatnya jika dilakukan. Sementara itu Lon Fuller dalam 8 (delapan) asas kepastian hukum mengemukakan salah satu dari kepastian hukum yang mengatakan "bahwa suatu peraturan itu harus dibuat dalam suatu rumusan yang mudah dimengerti oleh masyarakat umum". Dengan di tempatkannya seorang penyandang disabilitas autisme dalam kategori penyandang disabilitas mental dan konsep kecakapan bertindak yang tidak berbeda dengan konsep kecakapan bertindak sebagaimana KUHPerdata menimbulkan ketidakpastian hukum karena bertentangan dengan fakta dan juga menimbulkan kesulitan dalam memahami apa konsep yang jelas tentang kecakapan bertindak yang berlaku bagi penyandang disabilitas autisme itu.

Pada faktanya penyandang disabilitas autisme berbeda dengan penyandang disabilitas mental. Dan di dalam memahami konsep serta kriteria kecakapan bertindak bagi penyandang disabilitas autisme akan sangat sulit dipahami, apakah seorang penyandang disabilitas autisme adalah orang yang harus ditaruh dibawah pengampuan karena autisme adalah seorang penyandang disabilitas mental. Realitanya banyak yang secara keliru membedakan antara disabilitas mental, intelektual dan autis. Terkadang seorang autis dianggap seorang yang lemah akalnya dan terkadang juga dianggap orang yang gila. Memang terdapat ragam penyandang disabilitas autisme dan diantaranya memiliki IQ dibawah normal dan cenderung ke arah retardasi mental. Akan tetapi tidak semua penyandang autisme seperti itu. Satrio mengatakan bahwa pada asasnya yang dapat melakukan tindakan hukum secara sah dengan akibat hukum yang sempurna adalah mereka yang telah dewasa. Masalah ketidakcakapan bertindak di dalam hukum, tidak harus sesuai dengan kenyataan atau dengan kata lain, ketidakcakapan di sini adalah ketidakcakapan yuridis atau ketidakcakapan yang dipersangkakan (jurisische onbekwaamheid atau veronderstelde onbekwaamheid), bukan ketidakcakapan yang senyatanya (sesuai dengan kenyataan yang ada). ${ }^{35}$ Dengan menempatkan seorang penyandang disabilitas autis sebagai penyandang disabilitas mental menimbulkan berbagai macam penafsiran. Karena bisa saja meskipun seorang penyandang disabilitas autis itu seorang yang cakap baik secara usia dan intelektual, tetapi karena hukum dikatakan tidak cakap karena seorang yang menyandang disabilitas mental, karena itu penyandang disabilitas autis tidak akan pernah dapat dikatakan cakap secara yuridis akan tetapi cakap berdasarkan persangkaan dan bukan cakap karena yang senyatanya. Beccaria mengatakan bahwa interpretasi dalam hukum (undang-undang) adalah kegiatan buruk. Bagi Beccaria dua hal keburukan yang senantiasa ada di dalam hukum adalah ketidakjelasan hukum (undang-undang) dalam artian rumusannya dan yang kedua adalah keinginan untuk melakukan interpretasi sebagai akibat ketidakjelasan itu sendiri. ${ }^{36}$

\section{Penutup}

UU Penyandang Disabilitas merupakan suatu acuan hukum (kerangka hukum) bagi pemenuhan hakhak para penyandang disabilitas pada umumnya. Acuan hukum (kerangka hukum) dimaksud adalah dengan diakuinya penyandang disabilitas sebagai subyek hukum yang terdapat pada Pasal 9 UU Penyandang Disabilitas yang berisi tentang Hak keadilan dan perlindungan hukum untuk Penyandang Disabilitas. Akan tetapi Pasal 32 UU Penyandang

\footnotetext{
35 Ade Manan Suherman dan J. Satrio, Penjelasan Hukum Tentang Batasan Umur (Kecakapan Dan Kewenangan Bertindak Berdasar Batasan Umur), Jakarta: Nasional Legal Reform Program, 2010, hlm. 34.

36 Fernando M. Manullang. E, Legisme, Legalitas Dan Kepastian Hukum, Jakarta: Kencana, 2017, hlm. 108
} 
Disabilitas, juga menentukan bahwa tidak semua penyandang disabilitas cakap sebagai subyek hukum apabila Pengadilan Negeri menyatakan sebaliknya, yaitu "Penyandang Disabilitas dapat dinyatakan tidak cakap berdasarkan penetapan pengadilan negeri". Dengan menempatkan penyandang disabilitas autis ke dalam disabilitas mental sebagaimana yang terdapat di dalam penjelasan Pasal 32 UU Penyandang Disabilitas, dapat menimbulkan tafsir yang membuat seolaholah semua penyandang disabilitas autis adalah orang yang lemah atau tidak mampu berbuat sesuatu, baik untuk dirinya sendiri maupun untuk orang lain karenanya perlu dan harus ditempatkan dalam suatu pengampuan. Namun dengan samanya konsep dan kriteria kecakapan bertindak baik di dalam UU Penayandang Disabilitas dan juga di dalam KUHPerdata, yaitu bahwa cakap adalah seorang yang berusia dewasa dan tidak ditaruh dibawah pengampuan, maka seorang penyandang disabilitas autis yang telah berusia dewasa (menurut KUHPerdata usia dewasa adalah 21 tahun) dan tidak sedang ditaruh di bawah pengampuan adalah cakap menurut hukum (cakap secara yuridis) dan bukan cakap karena sesuatu yang dipersangkakan karena keadaannya.

\section{DAFTAR PUSTAKA}

Buku

Apeldoorn, L.J. Van, Pengantar Ilmu Hukum, Jakarta: Pradnya Paramita, 1983.

Ade Manan Suherman dan J. Satrio, Penjelasan Hukum Tentang Batasan Umur (Kecakapan Dan Kewenangan Bertindak Berdasar Batasan Umur), Jakarta: Nasional Legal Reform Program, 2010.

Fernando M. Manullang. E, Legisme, Legalitas Dan Kepastian Hukum, Jakarta: Kencana, 2017.

Maramis WF, Retardasi Mental Dalam Catatan IImu Kedokteran Jiwa, Surabaya: Airlangga University Press, 1994.

Satrio, J, Hukum Perjanjian, Bandung: Citra Aditya Bakti, 1992.

, Hukum Pribadi Bagian I Persoon Alamiah, Bandung: Citra Aditya Bakti, 1999.

Setiawan, I Ketut Oka, Hukum Orang dan Kebendaan, Jakarta: Sinar Grafika, 2016.

Sumaryono, Etika dan Hukum Relevansi Hukum Kodrat Thomas Aquinas, Jakarta: Kanisius,
2006.

Subekti, Pokok-Pokok Hukum Perdata, Jakarta: PT. Intermasa, 1992

\section{Tesis \& Jurnal}

Bertrand A. Hasibuan, "Problematika Kedewasaan Bertindak di dalam Hukum (Studi pada Praktik Notaris di Kota Medan)", Tesis, Universitas Sumatera Utara, 2006.

Hartono, B., Aspek neurologik Autisme Infantil. Seminar \& Work-shop on Fragile-X Mental Retardation, Autism and Related Disorders. Semarang: Badan Penerbit Universitas Diponegoro. 2002.

Mohamad Sugiarmin "Individu Dengan Gangguan Autisme", Jurnal Pendidikan Luar Biasa, Bandung: Universitas Pendidikan Indonesia, 2007.

S.A. Nugraheni, Menguak Belantara Autisme, Buletin Psikologi Volume 20, Fakultas Psikologi Universitas Gajah Mada, No. 102, 2012. 


\section{Perundang-Undangan Dan Peraturan}

Kitab Undang-Undang Hukum Perdata

Kitab Undang-Undang Hukum Pidana

Undang-Undang Nomor 1 Tahun 1974 tentang Perkawinan, Lembaran Negara Nomor 1 Tahun 1974

Undang-Undang tentang pengesahan Convention on the Right of Person with Disabilities (CRPD) (No. 19 Tahun 2011) tentang pengesahan Convention on the Right of Person with Disabilities (CRPD).

Undang-Undang Nomor 8 Tahun 2016 tentang Penyandang Disabilitas, Lembaran Negara Nomor 69
Internet

https://klinikautis.com/2011/10/24/gangguanstrukstur-dan-fungsi-otak-penderitaautism/

http://medicafarma.blogspot.com/2008/09/retard asi-mental.htm

https://www.rappler.com/indonesia/berita/17405 0

https://id.wikipedia.org/wiki/Skizofrenia.

https://id.wikipedia.org/wiki/Gangguan_bipolar.

https://id.wikipedia.org/wiki/Anxietas.

https://id.wikipedia.org/wiki/Depresi_(psikologi).

https://www.alodokter.com/gangguan-kepribadian. 